\title{
Sharia Arbitration as an Alternative Settlement of Sharia Banking Disputes
}

\author{
Muhamad Kholid \\ Sharia and Law Faculty State Islamic University \\ Sunan Gunung Djati Bandung, Indonesia \\ email: muhamadkholid@uinsgd.ac.id
}

\begin{abstract}
:
The enactment of Law Number 10 of 1998 concerning Amendments to Law Number 7 of 1992 concerning Banking, became an explicit formal juridical basis for the implementation of the Islamic banking system in Indonesia. These developments should be accompanied by anticipatory steps regarding the problem of settling the dispute. Law Number 30 of 1999 concerning Arbitration and APS (Alternative Dispute Settlement) responds to existing deficiencies by preparing dispute resolution institutions through arbitration. The type of arbitration authorized to settle Islamic banking in Indonesia is Sharia Arbitration so that Sharia Arbitration is the main choice for Sharia Banking business actors. This article will discuss the authority and effectiveness of Sharia Arbitration decisions in resolving Islamic banking disputes in Indonesia. The method used is normative juridical. The study was conducted with 2 (two) stages, namely: library research (library research) and field research (field research). Data collection is done by document study and interview. Data Analysis Method used is descriptive analytical with qualitative normative juridical approach. The results of the study concluded that Sharia Arbitration competencies can resolve sharia banking disputes which are part of the Islamic economy coupled with disputes which according to the law can be held peace.
\end{abstract}

Keywords: Alternative Dispute Settlement, Sharia Arbitration, Islamic Banking.

\section{A. INTRODUCTION}

Indonesia in mid-August 1997 was hit by the monetary crisis, the causes of which were uncontrolled inflation, large deficit balance of payment, ongoing trade restrictions, unbalanced exchange rate, unrealistic interest rates, burden swollen foreign debt and repeated capital inflows. Centralized and uneven development and not balanced with a democratic and just economic life (Agustianto, 2007:4). The fragile and undemocratic economic development eventually became the cause of the prolonged monetary crisis. The crisis has caused business bankruptcy, increasing unemployment, reducing the level of wages and purchasing power of the people, and increasing the number of people below the poverty line (Nasution, et.all., 1998:1).

The monetary crisis that occurred, had a negative impact on various areas of life such as economic, social, legal, political, and security. The crisis has made the Indonesian economy unstable, bankrupt companies and banks are liquidated, causing domestic and foreign investors to refuse to invest their capital in Indonesia by switching to neighboring countries that have more conducive conditions to invest.

During the reformation era, there were demands for reform or restructuring of various fields of life, so that a review of policies or regulations that regulated these fields needed to be reviewed. 
This is expected to be an evaluation material to reorganize national development programs in the future as stated in the National Medium Term Development Plan based on the National Development Planning System.

The economic sector is a field that must be prioritized in its development because it is in direct contact with people's lives and as a measure of the welfare standards of a country in the hope of becoming a support for the development of other fields. Economic development must be accompanied by development in the field of law as the main support so that development can be carried out in an orderly and according to plan. The government is currently trying to stabilize the national economy. The efforts made include: reducing inflation through Bank Indonesia policy, inviting and inviting investors both at home and abroad to invest, and making improvements to various existing regulations (deregulation), especially those that hamper investment or make rules to facilitate investment such as revising Taxation Laws, Capital Market Laws and Investment Laws. These efforts gradually bring positive changes to the national economy.

Indonesia's economic growth from year to year experienced growth, in 2015 there was a growth of $4.79 \%$ and increased in 2016 to $5.02 \%$ (www.cnnindonesia.com: 2017), in 2017 it increased to $5.05 \%$ and by 2018 , the government targeted economic growth of $5.4 \%$ (Primadhyta, 2017). National economic growth causes the business world to experience rapid development so as to be able to break through various dimensions of life and behavior of the human economy. Business development is inseparable from the influence of financial institutions called banks. Banks as business entities that collect funds and channel them to the public in the form of credit or other forms in order to improve the lives of many people.

Article 1 paragraph (12) of Law Number 7 of 1992 concerning Banking in conducting its business only vaguely gives an indication of the possibility of a bank providing financing facilities in return or profit sharing. The birth of Law Number 10 of 1998 concerning Amendments to Law Number 7 of 1992 concerning Banking (hereinafter referred to as the new Banking Law) has become a gateway for reform in the banking world, namely the development of bank businesses based on the Sharia Principles clearly including financing based on Mudharabah, Murabahah, Musyarakah and ljarah agreements. Establishment of Islamic Banks or banks that use Sharia Principles aims to anticipate the economic gap of Muslims in Indonesia. Therefore, Muslim scholars, scholars, and Muslim communities continue to encourage the Government to facilitate Muslims to have access to the banking world in order to increase their business through various loans without any element of usury.

Based on Sharia Banking Statistics Data until December 2017, Indonesian Islamic banking consists of 13 BUS with 1,817 offices with total assets of 288,027 billion, up from 254,184 billion in the previous year; 21 UUS with 343 offices with total assets of 136,154 billion, up from 102,320 billion in the previous year; The BPRS has 167 banks from the previous 166 in 2016 . These developments should be accompanied by anticipatory steps regarding the problem of settling the dispute. Dispute resolution through the judiciary is not recommended in the business world because it takes a long time, large costs, and is bound by judicial procedural law procedures so that an institution outside the court is required to cover these deficiencies. Law Number 30 of 1999 concerning Arbitration and Alternative Dispute Settlement (hereinafter referred to as Arbitration Law) responds to existing shortcomings by preparing a dispute resolution institution through arbitration.

Based on the recommendations of the MUI National Working Meeting, on 23-26 December 2002, confirming the change of name of BAMUI to the National Sharia Arbitration Board (National Sharia Arbitration Board), the amendment was based on the Decree of MUI Number Kep-09 / MUI XII / 2003 dated 24 December 2003 concerning National Sharia Arbitration Board. National Sharia Arbitration Board as the arbitral institution plays an alternative institution for resolving disputes 
outside the court in the field of Islamic economics. As long as National Sharia Arbitration Board is established and runs its operations from 1994-2016, there are 23 cases of Sharia Economic disputes with dominant cases of disputes in Islamic Banking. Therefore, this problem is very interesting to do further research because in addition to not many people doing research on Sharia arbitration, it is expected that this research can provide a clear picture of alternative dispute resolution through National Sharia Arbitration Board. The problem that will be discussed in this research is about the competence and application of the National Sharia Arbitration Board decision in resolving Sharia Banking disputes.

\section{B. LITERATURE REVIEW}

\section{Arbitration in the National Law Perspective}

a. Definition of Arbitration

Arbitration comes from the latin language, which is from the word "arbitrare" which means the power to resolve a case according to wisdom (Umar \& Kardono, 1995:2). There are several meanings of arbitration according to experts and the laws and regulations are as follows:

1) Subekti:

"Arbitration is a settlement of a dispute by a referee or referees who, according to agreement, will submit to or obey the decision that will be given by the referee or the referees they choose or appoint." (Subekti, 1979:1)

2) Sudargo Gautama:

"Arbitration is the method of resolving private judges who are not relatedto various formalities, are quick in giving decisions, because in the last instance and binding, that is easy to implement because it will be obeyed by the parties (Gautama, 1979:5)."

3) Abdulkadir Muhammad:

"Arbitration is a private judiciary outside the general court environment, which is known specifically in the world of companies. Arbitration is a court that is chosen and determined voluntarily by the parties to the dispute. Settlement of disputes outside the State Court is the free will of the parties. Will This freedom can be stated in the written agreement they made before and after the dispute in accordance with the principle of freedom of contract in civil law. " (Muhammad, 1993:276)

4) Article 1 paragraph (1) of the Arbitration Act:

"Arbitration is a way of resolving civil disputes outside the general court based on an arbitration agreement made in writing by the parties to the dispute."

Based on the above notions it can be concluded, that the meaning of arbitration is the settlement of civil disputes outside the general court conducted by a person or referees based on the written agreement of the parties before or after a dispute that is not related to various formalities and speedy in giving decisions.

\section{b. Legal Basis for Arbitration}

1) Article 10 paragraph (2) of Law Number 48 of 2009 concerning Justice, which reads as follows:

"This provision does not rule out the settlement of cases carried out outside the state court through peace."

2) Law Number 30 of 1999 concerning Arbitration and Alternative Dispute Settlement.

\section{c. Agreement and Arbitration Clause}


Article 1 point (3) of the Arbitration Act provides the definition of an arbitration agreement is an agreement in the form of an arbitration clause stated in a written agreement made by the parties before a dispute arises, or a separate arbitration agreement made by the parties after a dispute arises. Based on this rule, the basis for submitting a dispute settlement through arbitration can be done before a dispute occurs, called an Arbitration Clause (pactum compromitendo) or after a dispute occurs which is often called a Compromise Deed. This is reinforced by Article 7 of the Arbitration Law which reads: "The parties can approve a dispute that occurs or will occur between them to be resolved by arbitration."

\section{d. Types of Arbitration in Practice}

There are 2 (two) types of arbitration that can be chosen by the parties to settle the dispute, namely Ad hoc (voluntary) Arbitration and Institutional Arbitration (institution) (Usman, 2003:126). Ad hoc (voluntary) Arbitration is an arbitration formed specifically to resolve or decide on certain disputes, in other words Ad hoc Arbitration is incidental (Margono, 2004:123). While Institutional Arbitration is an institution or arbitration body that is permanent so that it is called "permanent arbitral body" ((Margono, 2004:124 \& Belohlávek, 2013:4). Example, Indonesian National Arbitration Board (BANI), National Sharia Arbitration Board (National Sharia Arbitration Board), Indonesian Capital Market Arbitration Board (BAPMI), Court of Arbitration of the International Chamber of Commerce (ICC), The International Center for Settlement of Investment Disputes (ICSID) and The United Nations Commission on International Trade Law (UNCITRAL).

\section{e. Arbitrator Requirements}

1) Arbitrator Requirements and Appointment.

The conditions for being appointed or appointed as an Arbitrator as stipulated

in Article 12 paragraph (1) of the Arbitration Act, include:

a) Capable of doing legal action;

b) At least 35 years old;

c) Have no blood relations or an affair up to a degree with one of the parties to the dispute;

d) Have no financial interest or other interest in the award;

e) Have experience and actively control the field for at least 15 years."

\section{f. Arbitration Competence}

Arbitration as one of the parties in the settlement of disputes of the parties has certain authority as stipulated in Article 12 paragraph (1) of the Arbitration Law. There are 2 streams regarding the agreement containing the agreement. arbitration, in the form of Pactum de Compromittendo or the Compromise Deed can override court competence or not, namely (Rosyadi dan Ngatino, 2002:82):

1) The arbitration clause is not a public order. This flow is implicit in the Netherland Raad van Justicy decision dated January 8, 1925 which contains the following verdict (Margono, 2004:126):

a) An arbitration clause relating to niet van openbaar order (not public order);

b) Disputes arising from the agreement containing the arbitration clause can be submitted to the Civil Court;

c) The court is still authorized to try as long as the opposing party does not submit an exception to the existence of a clause of the arbitration; 
d) The existence of an exception submitted, the other party is deemed to have "waived" his right to the arbitration clause in question;

e) Exception or breakdown of new arbitration clauses submitted in the reconciliation. The Defendant has been deemed to have waived his right to the arbitration clause and the authority to adjudicate the dispute has fallen and is subject to the jurisdiction of the Court.

This School argues that arbitration is not absolute. The clause must be maintained by the parties so that it will remain binding. If a dispute arising from an agreement containing an arbitration clause is submitted by one of the parties to the court, the court has the authority to adjudicate. Authority has only been terminated if the defendant submits an exception to the arbitration clause.

\section{g. Arbitration Clause is Pacta Sunt Servanda.}

This school starts with the legal doctrine that teaches that all legitimate agreements will bind and become laws for the parties. Therefore, every agreement can only be terminated (withdrawn) by mutual agreement of the parties. The principle of Pacta Sunt Servanda is contained in Article 1338 paragraph (1) of the Civil Code which states:

"Every agreement made legally applies as a law for those who make it".

Starting from the principle of Pacta Sunt Servanda. This school argues or gives the opinion that any agreement containing the arbitration clause (Margono, 2004:127):

a) Binding absolutely to the parties;

b) Authority to examine and decide on disputes that arise as absolute authority.

An agreement or arbitration clause is a foundation for a modern international commercial arbitration. It has the following functions (Adolf, 1994: 31):

a) Show the parties have agreed to settle the dispute through arbitration;

b) If the parties have agreed to arbitrate the agreement cannot be withdrawn by one of the parties;

c) The agreement becomes the source of arbitration authority Based on Article 3 of the Arbitration Law which reads:

"The District Court is not authorized to adjudicate disputes between parties that have been bound by the arbitration agreement."

Therefore, the arbitration institution is the only institution authorized to receive, examine, hear, decide and resolve disputes which in its written agreement determine arbitration as the choice of forum.

\section{h. Arbitration Dispute Object}

The object of the dispute that can be resolved by arbitration is only disputes in the civil field. Article 5 paragraph (1) of the Arbitration Act reads:

"Disputes that can be resolved through arbitration are only disputes in the trade sector and regarding rights which according to law and regulations are fully controlled by the disputing parties." This provision is closely related to the explanation of Article 66 of the Arbitration Law which details the scope of trade, among others in the fields of:
1) Preparation;
2) Banking;
3) Finance;
4) Investment;
5) Industry; 
6) Intellectual Property Rights "

Article 5 paragraph 2 of the Arbitration Act reads:

"Disputes that cannot be resolved through arbitration are disputes which according to the laws and regulations there cannot be peace." If using the interpretation of argumentum a contrario, the object of an arbitration dispute is a dispute in the field of trade and the rights which according to the law can be held peace. As long as the settlement of trade disputes and peace rights can be held, the settlement can be submitted to the arbitration institution (Usman, 2003:126).

\section{i. Arbitration Examination Process}

The Arbitration Examination Process is regulated in Article 27-48 of the Arbitration Act which describes the following: Examination of cases carried out in arbitration is conducted in a closed manner using Indonesian language or other language with the approval of the arbitrator or the Arbitration Tribunal. Each disputing party has the same rights and opportunities in expressing their opinions and the parties can be represented by their proxy with a Special Power of Attorney. An examination of the dispute must be completed within a maximum period of 180 days after the Arbitrator or Arbitrator Council is formed. The Arbitrator or Arbitrator Council is authorized to extend the term of his duty if:

1) Requests submitted by one of the parties regarding certain specific matters;

2) As a result of the stipulation of provisional decisions or other interlocutory decision;

3) Considered necessary by the Arbitrator or Arbitrator Council for the purpose of examination.

The third parties outside the arbitration agreement can participate and merge in the dispute resolution process through arbitration if there is an element of related interest and its participation is agreed upon by the parties to the dispute and approved by the arbitrator or the Arbitral Tribunal who examines the dispute concerned. The parties to the written agreement are free to determine the arbitration procedural law used in the examination of the dispute, as long as it does not conflict with the provisions of the Arbitration Law. In addition, there must be an agreement regarding the period of arbitration. If the period and place of arbitration are not determined, the Arbitrator or Arbitrator Council will determine. The Arbitration Law provides legal means for requesting one of the parties to the Arbitrator or Arbitrator Council to be able to take an interim decision in regulating the orderliness of the way to examine disputes, including among others:

1) Determination of guarantee bail;

2) Ordering safekeeping of goods to third parties;

3) Selling items that are easily damaged.

\section{j. Evidence Tool in Arbitration Procedure Law.}

When the parties designate the Indonesian procedural law in proof, then as evidence refers to Article $164 \mathrm{HIR}$. Legal evidence according to the provisions consists of (Saleh, 1983:114):

1) Letter of evidence;

2) Tool of evidence of witness testimony;

3) Recognition evidence;

4) Oath proof;

5) Proof of evidence. "

\section{k. Arbitration Decission}


The arbitration award only binds the two parties who entered into an agreement if carried out in accordance with the applicable law. Article $631 \mathrm{Rv}$. places a principle that an arbitral award must be based on the applicable laws and regulations in the disputed field, in the Indonesian law and regulations (Harahap, 1989:670). Article $631 \mathrm{Rv}$. is translated by the referees to make decisions according to the laws and regulations, unless according to the compromise, they are given the authority to decide as human beings based on justice. Article 52 of the Arbitration Act explains that the parties have the right to request binding opinions from arbitration institutions on certain legal relations of an agreement. Therefore, the arbitral institution can accept requests submitted by the parties in an agreement and provide a binding opinion (opinion opinion) regarding the matter relating to the agreement, such as the interpretation of unclear provisions, additions or changes in provisions relating to the emergence of circumstances the new one. The giving of opinion by the arbitration institution causes both parties to be bound to it. If the action of one of the parties contradicts that opinion, it is considered to violate the agreement. Against the binding opinion as referred to in Article 52, resistance can not be submitted through any legal remedy. An arbitration decision which is not signed by one of the arbitrators on the grounds of illness or death does not affect the force of the decision.

\section{Implementation of Arbitration Award}

The execution or execution of the decision is carried out within a maximum period of 30 days from the date the verdict is pronounced, the original or authentic copy of the arbitral award is submitted and registered by the arbitrator or his attorney to the District Court Registrar. Submission and registration is carried out by recording and signing at the end or at the edge of the decision by the District Court Registrar and the arbitrator or the proxy who submits, and the record is a Registration Deed.

The arbitrator or his attorney is obliged to submit the verdict and the original sheet of appointment as an arbitrator or an authentic copy to the District Court Registrar. This is a condition and if it is not fulfilled, the arbitration award cannot be implemented and all costs related to the making of the Registration Deed are charged to the parties. The arbitration award is final and has permanent legal force (in kracht) and is binding on the parties. The final decision means that the award cannot be appealed, appealed, or reviewed. Both parties to the dispute are bound by the decision and therefore must implement it voluntarily. If one party defaults, the local district court has the right to execute.

\section{m. Legal Effort for Arbitration Decisions}

Legal remedies against the Arbitration Award are regulated in Article 71-72 of the Arbitration Act, namely: Regarding the arbitration award, the parties can submit a request for cancellation if the decision is alleged to contain the following elements:

1) The letter or document submitted in the examination after the verdict has been handed down is admitted to be false or declared false;

2) After the decision has been taken, a decisive document is found which is hidden by the opposing party;

3) Decisions are taken from the tricks made by one of the parties in the examination of the dispute."

The request for cancellation of the arbitral award must be submitted in writing within 30 days from the day of submission and registration of the arbitration award to the Registrar of PN. With regard to the PN decision, the parties can submit an appeal to the Supreme Court which decides in the first and last level. Consideration and decision of the Supreme 
Court on the appeal petition is issued within a maximum period of 30 days after the appeal was received by the Supreme Court.

\section{n. Sharia Banking in Indonesia}

Definition of Islamic Banking in Article 1 paragraph (1) of Law Number 21 of 2008 concerning Sharia Banking, namely: Sharia Banking is everything concerning Sharia Banks and Sharia Business Units, including institutions, business activities, and ways and processes in carrying out its business activities. Sharia Banking Legal Sources are: Qur'an, Hadith, ljma' (Scholar Consensus), Qiyas (Analogy), Civil Code/BW, Law Number 7 of 1992 concerning Banking, Law Number 8 of 1998 concerning Amendments to Law Number 7 of 1992 concerning Banking, Law Number 21 of 2008 concerning Sharia Banking, Law Number 23 of 1999 concerning Bank Indonesia, Law Number 3 of 2004 concerning Amendments to Act Number 23 of 1999 concerning Bank Indonesia, Bank Indonesia Regulation, Bank Indonesia Circular Letter, Law Number 21 of 2011 concerning the Financial Services Authority, Financial Services Authority (Otoritas Jasa Keuangan [OJK]) Regulation, Fatwa of the National Sharia Council (Dewan Syariah Nasional [DSN] Indonesian Ulama Council (Majelis Ulama Indonesia [MUI]), and Supreme Court Regulation Number 2 of 2008 concerning Compilation of Sharia Economic Law.

\section{Sharia Banking Principles}

Sharia Banking in conducting its business activities based on Sharia Principles, economic democracy, and prudential principles. Sharia Banking aims to support the implementation of national development in order to improve justice, togetherness and equality of people's welfare. Islamic Banks and Sharia Business Unit (Unit Usaha Syariah [UUS]) are obliged to carry out the function of collecting and distributing public funds.

Sharia Banks and Sharia Business Unit can carry out social functions in the form of Baitul Mal institutions, namely receiving funds derived from zakat, infaq, alms, grants, or other social funds and channeling them to zakat management organizations. Sharia Banks and UUS can collect social funds derived from money waqf and channel it to waqf managers (Nazhir) according to the will of the waqf (wakif).

\section{RESEARCH METHODOLOGY}

The approach used in this research is normative juridical, namely legal research conducted by researching and reviewing library materials or so-called secondary materials, which may include primary, secondary and tertiary legal materials (Soekanto, 1986:52). In the form of positive law such as act of religious court law and how to implement the principles of National Sharia Arbitration Board (Badan Arbitrase Syariah Nasional/Basyarnas) in practice.

Through this approach will be expressed analytically descriptive that is to describe systematically, factually and accurately, all the facts and problems under study are associated with legal theories and the practice of conducting National Sharia Arbitration Board in accordance with the identification of problems. The intention is to provide as accurate data as possible about humans, circumstances or other phenomena. Then the description is analyzed by starting from religious court law, theories, and opinions of experts who aim to find and get answers to the points that will be discussed further.

This research was conducted by analyzing the competence and application of National Sharia Arbitration Board decisions in religious court law in two stages, including: 
1. Library Research that is carried out by analyzing legislation both in the form of primary legal materials and secondary legal materials that apply in Indonesia.

a. Primary legal materials that is material law which is binding and related such as Qur'an, Hadith, ljma (Scholar Consensus), Qiyas (Analogy), 1945 Constitution, Code of Civil law, Law Number 7 of 1992 concerning Banking, Law Number I 0 of 1998 Regarding Amendment to Law Number 7 of 1992 concerning Banking, Law Number 30 of 1999 concerning Arbitration and APS, Law Number 14 of 1970, Law Number 35 of 1999, Law Number 4 of 2004 concerning Power Justice, Law Number 7 of 1989 concerning religious court law, Law Number 3 of 2006 concerning Amendments to Law Number 7 of 1989 concerning religious court law, Law Number 25 of 2004 concerning National Development Planning System and Presidential Regulation Number 7 of 2005 concerning the National Medium Term Development Plan of the Year 2004-2009.

b. Secondary legal material, namely legal materials that explain primary legal materials and can help analyze and understand primary legal materials, among others: the scientific work of legal experts relating to the problems studied or relating to primary legal materials, including books, results research related to arbitration, especially regarding Sharia Arbitration.

c. Tertiary legal material, namely legal material that provides guidance and explanation of primary and secondary materials, such as legal dictionaries, articles, journals, newspapers, magazines, and official websites on the internet relating to arbitration, especially regarding Sharia Arbitration.

2. Field Research (field research)

Field research is collecting, researching and analyzing primary data obtained directly from the field to support secondary data or to support library data by revealing important information and responses or opinions about Sharia Arbitration in the Jakarta National Sharia Arbitration Board Center.

3. Data Collection Techniques

a. Document Study that is conducting research on documents that are closely related to National Sharia Arbitration Board activities, in order to obtain a theoretical foundation in the form of opinions or scientific work of experts or other parties and obtain information in formal form and data through existing official texts.

b. Interview that is an in-depth data collection technique with a question and answer process between the researcher and the respondent to obtain primary and secondary data directly consisting of institutions that are involved in the off-court dispute settlement activities, namely National Sharia Arbitration Board. This interview was carried out by first preparing the interview guidelines addressed to the National Sharia Arbitration Board Management or arbitrator.

4. Data Analysis Methods

Data Analysis Method used is analytical descriptive with a qualitative normative juridical approach which is an approach taken from the conclusions of researchers from the results of research that has been done with qualitative normative analysis methods. Normative because the prevailing laws and regulations as a positive law are the source or starting point in this thesis study, while qualitative because the information found through interviews and discussions delivered by the parties related sources is used to obtain a data analysis without using numbers.

\section{FINDINGS AND DISCUSSION}




\section{Sharia Arbitration Competency as an Alternative Institution for Dispute Resolution.}

Article 1 paragraph (1) of the Arbitration Law provides that arbitration is one of the settlement of civil disputes outside the general court based on an arbitration agreement made either before or after the dispute occurred. Sharia Arbitration is a type of institutional arbitration institution whose legal umbrella based on the Arbitration Law is strengthened by internal regulations, namely the Regulations Procedure of the National Sharia Arbitration Board (National Sharia Arbitration Board). In Article 2 of the National Sharia Arbitration Board Procedure Regulations read as follows:

"Agreement to: hand over the settlement of the dispute to National Sharia Arbitration Board, carried out by the parties:

a. By including an arbitration clause in a draft agreement or;

b. With a separate arbitration agreement made and approved by the parties, both before and after the dispute arises. "

The arbitration agreement made by the parties is binding because the legal force is the same as the law so that the parties must implement it. This is based on Article 1338 paragraph (1) of the Civil Code which reads:

"Every agreement made legally applies as a law for those who make it."

Thus, the existence of an arbitration agreement that submits the dispute settlement of the case to the Sharia Arbitration Institution is the legal basis while providing authority (absolute competence) to Sharia Arbitration. If there is one party requesting the settlement of the dispute back to the District Court (PN), the PN must refuse it. This is based on Article 3 of the Arbitration Law which reads:

"The District Court is not authorized to adjudicate disputes between parties that have been bound by the arbitration agreement."

Sharia Arbitration Competency in resolving muamalah disputes is also based on the DSN's fatwa which regulates muamalah relations by listing the Sharia Arbitration Clause in each of its fatwa, namely:

"If one of the parties does not fulfill its obligations or if there is a dispute between the two parties, then the settlement is carried out through the Sharia Arbitration Board after an agreement is not reached through deliberation."

Whereas the regulation in Law Number 21 of 2008 concerning Sharia Banking (hereinafter referred to as the Sharia Banking Law) is explained in Article 55 paragraph (2) which reads as follows:

"In the event that the parties have agreed to settle the dispute other than as referred to in paragraph (1), the settlement of the dispute is carried out in accordance with the contents of the contract."

Elucidation of Article 55 paragraph (2) of the Sharia Banking Act is as follows:

What is meant by settlement of disputes carried out in accordance with the contents of the contract is the following efforts:

a. Discussion;

b. Banking Mediation;

c. Through the National Sharia Arbitration Board (National Sharia Arbitration Board) or other arbitration institutions and / or;

d. Through the court in the general justice environment.

Sharia Arbitration in carrying out its duties and authorities is based on the Arbitration Law and internal regulations. Arrangements regarding the object competence 
of arbitration disputes in the Arbitration Law are regulated in Article 5 paragraph (1) and (2) which read:

"Disputes that can be resolved through arbitration are only disputes in the trade sector and regarding rights which according to law and regulations are fully controlled by the disputing parties. Disputes that cannot be resolved through arbitration are disputes that according to the law cannot be held peace."

The trade sector in question includes: Commerce; Banking; Finance; Capital investment; Industry; and Intellectual Property Rights, As set out in the explanation of Article 66 letter (b) of the Arbitration Act. Whereas in paragraph (2) explains that disputes that are not an object of arbitration competence are disputes that cannot be held by peace. When using the interpretation of argumentum a contrario, the object of an arbitration dispute is a dispute in the field of trade and the rights which according to the law can be held peace. As long as the settlement of trade disputes and peace rights can be held, the settlement can be submitted to the arbitration institution.

In general, the object of Sharia Arbitration competence is to resolve muamalah disputes. When viewed in terms of understanding, muamalah has 2 (two) understandings. First, muamalah in the broad sense is the rule (the law of God) to regulate humans in relation to worldly affairs and social relations. Second, the notion of muamalah in a narrow sense is the rule of God that must be obeyed which regulates human relations with humans in relation to how to obtain and develop property (Suhendi, 2002:2-3). The thing that distinguishes the notion of muamalah in the broad and narrow sense is in its scope. Muamalah in a broad sense covers the issue of inheritance and marriage while in a narrow sense it is not included because the inheritance problem has its own scientific discipline, namely in mawaris jurisprudence and marital problems in munakahat fiqh.

National Sharia Arbitration Board internal regulation which regulates the object of the dispute which is the competence of National Sharia Arbitration Board is regulated in Article 2 paragraph (1) of the National Sharia Arbitration Board Basic Guidelines which reads:

"The National Sharia Arbitration Board is tasked with providing a fair and fast settlement in muamalah / civil disputes arising in the fields of trade, finance, industry, services, and others."

The National Sharia Arbitration Board internal regulation stipulates that the jurisdiction of National Sharia Arbitration Board, among others, resolves fairly and quickly muamalah / civil disputes arising in the fields of trade, finance, industry, services, and others which according to law and regulations are fully controlled by the disputing parties.

Thus, a temporary conclusion can be drawn that the object of National Sharia Arbitration Board competency is to resolve the muamalah dispute in a narrow sense which includes disputes in the trade sector, including: Displaying, Banking, Finance, Investment, Industry, Intellectual Property Rights, and Services that use Sharia Principles and other disputes another that can be pursued by peace.

There are several reasons why the parties appoint a Sharia Arbitration as a Sharia Banking dispute settlement institution as follows:

a. National Sharia Arbitration Board is a hakam institution (Sharia arbitration) whose legal guidelines based on Islamic law, especially Muamalah Fiqh, are included in resolving Sharia Banking disputes. 
b. National Sharia Arbitration Board has the duty to provide fair and fast settlement in muamalah / civil disputes arising in the field of Trade, including Sharia Banking, Finance, Industry, Services, and others;

c. National Sharia Arbitration Board in carrying out its duties and functions as a National Sharia Arbitration Board Hakam institution is autonomous and independent.

Thus the role of National Sharia Arbitration Board in the settlement of disputes holds on the priority of striving for the best possible settlement of disputes with voluntary appeals, namely:

a. Invite and direct peace (ishlah);

b. Peace is sought from the beginning before the examination until the verdict;

c. In the event of a peace agreement, the formulation is submitted to the parties.

National Sharia Arbitration Board in completing the implementation of the legal principles that are upheld (governing law), namely (Harahap, 1994:114):

a. Every party that agrees to the settlement of a dispute by National Sharia Arbitration Board means submitting itself to the Sharia values. Thus the principle of governing law applied by National Sharia Arbitration Board must be in accordance with Sharia.

b. Governing law must not conflict with the Law and public order because:

1) In accordance with the principle of freedom of contract;

2) In accordance with the principle of freedom to choose the governing law desired by the parties;

3) Islamic law is a value that takes place in the national law as a positive law.

\section{Application of Sharia Arbitration Decision in Completing Sharia Banking Disputes.}

National Sharia Arbitration Board as a hakam institution in its decision is final and binding, as stipulated in Article 25 paragraph (1) of the National Sharia Arbitration Board Procedure Regulations which read:

"National Sharia Arbitration Board Decision that has been signed by a Sole Arbitrator or Arbitrator of the Assembly is Final and Binding (final and binding) for the parties to the dispute, and must be obeyed and carried out voluntarily."

This provision is in accordance with Article 60 of the Arbitration Act which reads:

"The arbitration award is final and has permanent legal force and binds the parties".

It is final meaning that the arbitration award is the final decision and therefore legal remedies cannot be filed such as appeals, cassation or reconsideration. Having legal power still means that the arbitral award becomes the legal basis for voluntary or forced execution through the court. Binding the parties means that the arbitral award is legally binding on the parties to accept and implement the decision as they determine the arbitration as the institution for resolving the dispute contained in the arbitration agreement or clause.

National Sharia Arbitration Board arbitrators in making decisions based on legal provisions or based on justice and propriety (ex aquo et bono). Previously the arbitrator's decision was taken based on deliberation/consensus and if the consensus was not reached then the decision was taken based on the most votes (voting). When the majority of votes are not reached, the Chair of the Arbitrator of the Assembly can take his own decision and the decision is considered to be taken by all the Arbitrators of the Assembly with regard to various inputs from other members of the arbitral tribunal.

Copies of decisions that have been signed by a Sole Arbitrator or Arbitrator of the Assembly are given to each Petitioner and the Respondent and the decision may not be announced, unless agreed by the parties. This is done because the most important thing in the settlement of the dispute 
through arbitration is confidentiality. The benefit is to safeguard the good name of the parties, safeguarding negative publicity that will adversely affect its business operations.

The decision issued by National Sharia Arbitration Board includes:

1. Basmallah's sentence which reads: Bismillaahirrahmaanirrahiim above the decision's head.

2. The head of the verdict reads: "For the sake of Justice Based on the Almighty God".

3. The full name and address of the parties

4. A brief description of the dispute

5. Establishment of the parties

6. Complete narrator of arbitrators

7. Consideration and conclusions of the Sole Arbitrator or the Arbitrator of the Assembly regarding the entire dispute

8. The opinion of each arbitrator in the event that there are differences of opinion in the arbitrator council

9. Amar decision

10. Place and date of decision

11. Signature of arbitrator or Arbitral Tribunal.

Decisions issued by National Sharia Arbitration Board can be executed directly by the parties voluntarily because in the ruling contained the "For Justice By virtue of the Almighty God". Whereas if the decision is not carried out voluntarily, the arbitration award shall be carried out according to the following provisions:

1. "When the parties do not implement the arbitral award voluntarily, the decision is carried out based on the order of the Chairman of the PN on the request for execution of one of the parties to the dispute.

2. The PN Chairperson's order for an execution request is given within 30 days after the execution request is registered with the PN Registrar.

3. The Chairman of the PN before giving an order to execute the execution, first checking whether the arbitral award fulfills the provisions of Article 4 and 5 of UUA and does not conflict with decency and public order

4. When the decision does not fulfill the provisions of Article 4 and 5 of UUA and does not conflict with decency and public order, the Chairperson of PN rejects the application for execution and the decision of the Chairperson of the PN is not open in any legal proceedings.

5. The Chairperson of the PN does not examine the reason or consideration of the arbitration award

6. The Chair of the PN Chair is written on the original sheet or an authentic copy of the arbitration award

7. An arbitration award that has been affixed with the order of the Chairman of the PN, is carried out in accordance with the provisions of the implementation of the decision in a civil case whose decision has permanent legal force. "

Article 4 of the Arbitration Law explains that in the event the parties have agreed that a dispute between them will be resolved through arbitration and the parties have given authority, the arbitrator has the authority to determine in his decision the rights and obligations of the parties if this is not regulated in their agreement with the provisions approval to settle a dispute through arbitration as referred to in paragraph (1) is contained in a document signed by the parties. In the event that an arbitration settlement is agreed upon in the form of an exchange of letters, the sending of telex, telegram, facsimile, e-mail or other forms of communication must be accompanied by an acceptance note by the parties. 
The Chairman of the PN before giving an order for execution of the National Sharia Arbitration Board decision first checks the following matters:

1. "The parties agree that the dispute between them will be resolved through arbitration;

2. Approval to settle disputes through arbitration is contained in a document signed by the parties;

3. Disputes that can be resolved through arbitration are only disputes in the trade sector and regarding legal rights and laws and regulations;

4. Other disputes that can be resolved through arbitration are those that do not conflict with decency and public order."

At the latest 30 days from the date the decision is read, the original or authentic copy of the arbitral award is submitted and registered by the arbitrator or his proxy to the PN Registrar. Submission and registration: the date is done by recording and signing at the end or at the edge of the decision by the PN Registrar and the arbitrator or his proxy, and the record is a Registration Deed.

Based on the results of interviews with Drs. Euis Nurhasanah as the Secretary of National Sharia Arbitration Board, since its establishment on October 21, 1994 until 2015, has at least successfully completed 23 business disputes. In 1993-2009 there were 17 cases, in 2010-2015 there were 6 cases. Among them are:

1. Case Number 1 began to convene on July 26, 1997 until the decision dated December 30, 1997.

2. Case Number 2 began the trial on September 29, 1998 until the verdict on April 3, 2000. The length of the settlement process was due to a request from both parties to look at the collateral items so that the parties requested an extension of the time period for delaying the proceedings in the National Sharia Arbitration Board.

3. Case Number 3 began hearing on December 26, 1998 until the verdict dated June 11, 1999.

4. Case Number 4 began the trial on March 6, 1999 until the verdict dated May 21, 1999. The speed of the inspection process was due to the request to give up the claim from the applicant.

5. Case Number 5 began the trial on September 3, 1999 until the decision dated December 12, 2001.

6. Case Number 6 starts the trial on October 5, 2000 until the decision on December 30, 1997.

The difference between National Sharia Arbitration Board and other arbitration institutions

is that there is the possibility of a free case investigation (prodeo) by attaching a statement of minimal inability from the kelurahan. This provision is regulated in Article 4 paragraph (4) of the National Sharia Arbitration Board Procedure Regulations which read:

"If the parties are unable to pay the registration fee, and the examination fee which can be proved by an official statement from at least the local village head, the Chairperson of the National Board can determine their policy."

There are provisions regarding the possibility of prodeo litigation for those who cannot, this illustrates that one of the National Sharia Arbitration Board characters who in their activities must always be balanced. Balanced in the sense of not forgetting the interests of the community or the weak economic group because it is an obligation to safeguard the legal interests of those who are unable to pay the registration fee, and the examination fee to continue to get justice. Thus National Sharia Arbitration Board in carrying out his functions and authority is not merely seeking profit (profit oriented) but still maintaining social values.

22 years (1993-2015) was a long time but only 23 cases were examined and ruled. There are several weaknesses of National Sharia Arbitration Board in carrying out their functions and authority, namely:

\section{Don't have specific rules}


National Sharia Arbitration Board as one of the Arbitration institutions that resolves the muamalah dispute in a narrow sense, the legal basis still refers to the Arbitration Law as a general rule that regulates the settlement of disputes outside the court, namely through arbitration and APS including ways of Negotiation and Mediation. While the Arbitration Law does not regulate specifically National Sharia Arbitration Board such as its functions and authorities but only regulates in terms of institutional and procedural law in general as stipulated in Article 1 paragraph (1) concerning the meaning of arbitration and Article 1 paragraph (8) concerning the meaning of arbitration institutions. The Arbitration Law also has no rules explaining arbitration institutions that are authorized to resolve muamalah disputes arising from the Trade sector, including: Commerce, Banking, Finance, Investment, Industry, Intellectual Property Rights, and Services that use Sharia Principles and other disputes that can peace efforts including Sharia Economic disputes, especially Islamic Banks. The absence of regulation regarding Sharia Arbitration in the form of a Law as a specialist lex from the Arbitration Law, has a legal effect on the decision issued by National Sharia Arbitration Board itself which is a less than perfect Sharia Arbitration decision. Therefore, the demand for awareness from the parties to voluntarily implement a Sharia Arbitration decision has a dominant role for the effectiveness of an arbitral award. Nonetheless, every National Sharia Arbitration Board decision issued is a final decision and has a legal force that binds the parties. If one party does not carry out the decision voluntarily, it can be requested to execute the court. This can be seen in the arrangement in UUA or can be seen in the National Sharia Arbitration Board Procedure Regulations.

2. Do not have the right to carry out a full execution

Basically, the arbitrator's ruling has executive strength, in the sense that the arbitral award can be made directly by the parties because in the decision there is an official "For the sake of Justice Based on the Almighty God". But sometimes one of the parties still does not want to accept and even carries out the decision. Therefore, the execution of an arbitration award can be carried out through a court institution. This is due to the fact that the arbitration body does not have a legal basis or legal instrument to carry out the confiscation, auction or the process of vacating the disputed building so that this results in one party having to incur costs to finance the execution.

However, based on the results of an interview with Achmad Djauhari as the Secretary of Basyarnas on June 24, 2007, there are opportunities that National Sharia Arbitration Board has as one of the arbitration institutions in resolving disputes outside the judiciary as follows:

1. National Sharia Arbitration Board is the only Sharia Arbitration in Indonesia authorized to resolve muamalah disputes whose legal guidelines use Islamic law, especially Muamalah Figh. The growth and development of Sharia Economy in Indonesia, especially in the area of Islamic Banks which has experienced very rapid development supported by its material legal instruments such as the Banking Law, the Bank Indonesia Law and the rules of its implementation and added that now there is a Sharia Banking Draft Law, this becomes a separate opportunity for National Sharia Arbitration Board to provide the best service in resolving Sharia Banking disputes.

2. Having an advantage over the settlement carried out through other arbitration institutions or judicial institutions. Among them is the principle of the Arbitration trial which is closed to the public while the Court is open to the public. When looking at Islamic law, there is an order for believers to stay away from prejudice, because some prejudice is a sin and not to seek fault with others and a ban on gossip. Thus, the trial conducted by arbitration with the principle of being closed to the public is more in line with the teachings of Islamic law. The trial process in arbitration is conducted in a familial manner with the principle of reconciling (ishlah) by simplifying and even avoiding formalistic prosuderal while the trial process in the judiciary positions the parties against the strict formalistic procedure. The arbitration examination process 
must be completed within a maximum period of 180 days after the arbitrator or arbitrator assembly is formed. Examination conducted by the judiciary does not have a time limit for completion and even requires a very long time because it is given an opportunity for parties who are less satisfied to make legal action such as appeals, cassation and reconsideration. The arbitration award is final and binding so there is no opportunity to make an appeal. The arbitral award also has executorial power that can be executed directly by the parties in a voluntary manner. If the decision is not made voluntarily, the execution is carried out through the local district court while the decision issued by the court is not final because there are still opportunities for legal action.

3. The number of inclusion of Sharia Arbitration in the agreement or arbitration clause in this case is National Sharia Arbitration Board, a separate opportunity to truly be prepared to anticipate the emergence of disputes, especially disputes arising from the muamalah field, especially in the fields of trade, finance, industry, services that use Sharia Principles.

4. The growing development of businesses that use Sharia Principles in carrying out their operational activities such as the Sharia Economy, Islamic Money Markets, Islamic Capital Articles, Islamic Pawnshops, and Islamic Venture Capital.

\section{E. CONCLUSION}

1. Sharia Arbitration has absolute competence if it is regulated in writing in an Arbitration Agreement or there is an Arbitration Clause with the object of competence to resolve muamalah disputes in a narrow sense arising from the Trade field, including: Commerce, Banking, Finance, Investment, Industry, Rights Intellectual Property, Services that use Sharia Principles and other peace-related disputes including Sharia Banking disputes.

2. National Sharia Arbitration Board Decisions are final and binding, therefore legal remedies cannot be submitted. Upon this decision, execution can be carried out directly by the parties voluntarily. If the decision cannot be done voluntarily, the decision will be carried out through the Chairperson of the PN.

In order for Sharia arbitration decisions to be effective, the parties need to know or have an understanding and awareness of the law, especially Islamic law.

\section{BIBLIOGRAPHY}

\section{A. Books}

A. Rahmat Rosyadi dan Ngatino, Arbitrase dalam Perspektif Islam dan Hukum

Positif, PT Citra Aditya Bakti, Bandung, 2002.

Adiwarman A. Karim, Bank Islam Analisis Fiqih dan Keuangan, RajaGrafindo

Persada, Jakarta, 2004;

Abdulkadir Muhammad, Pengantar Hukum Perusahaan Indonesia, PT. Citra Aditya

Bakti, Bandung, 1993.

-----, Hukum Perusahaan Indonesia, PT. Citra Aditya Bakti, Bandung, 2002.

Abdul Azis Dahlan, Ensiklopedi Hukum Islam, Jilid 3, PT. Intermasa, Jakarta, 2001. 
Abdul Hakim, Al-Bayan, Sa'diyah Putra, Cet ke-II , Jakarta, 1972.

Abdul Wahab Khallaf, IImu Ushul Al-Figh, Dar-al-Kuwatiyah, 1968.

Abu Walid Muhammad Al-Andalusi, Bidayatul Mujtahid, Dar Ihya Al-Kutub Al-Arabiyah, Indonesia.

Atang Abd Hakim dan Jaih Mubarok, Metodologi Studi Islam, PT. Remaja Rosda Karya, Bandung, 2000.

Al-Shan'ani, Subulu al-Salam, Al-Masyhad Al-Husaini, Kairo.

Anshoruddin, Hukum Pembuktian Menurut Hukum Acara Islam dan Hukum Positif, Surabaya, 2004.

Achmad Djauhari, Arbitrase Syariah Di Indonesia, National Sharia Arbitration Board, Jakarta, 2006.

Abdul Ghofur Anshori, Peradilan Agama Di Indonesia Pasca. UU No. 3. Tahun 2006, UI Press, Yogyakarta, 2007.

National Sharia Arbitration Board, Profil dan Prosedur Badan Arbitrase Syariah, Nasional (National Sharia Arbitration Board), National Sharia Arbitration Board, Jakarta, 2006.

Djuhaendah Hasan, Lembaga Jaminan Kebendaan Bagi Tanah dan Benda Lain Yang Melekat Pada Tanah Konsep Penerapan Horizontal, Binacipta, Bandung, 1996.

Dede Rosyada, Hukum Islam dan Pranata Sosial, Dirasah Islamiyah III, RajaGrafindo Persada, Jakarta, 1999.

Departemen Pendidikan Nasional Universitas Padjadjaran, Pedoman Penulisan Tesis/Disertasi Program Pascasarjana Tahun Akademik 2005-2006, Bandung, 2005.

Fathur Rahman, Hadits-hadits tentang Peradilan Islam, Bulan Bintang, Jakarta, 1977. Gemala Dewi, (et.all), Hukum Perikatan Islam Di Indonesia, Prenada Media, Jakarta, 2005. Huala Adolf, Hukum Arbitrase Komersil Internasional, PT. RajaGrafindo Persada, Jakarta, 1994.

-----, Hukum Penyelesaian Sengketa Internasional, Sinar Gafika, Jakarta, 2004.

Hendi Suhendi, Fiqih Muamalah, PT RajaGrafindo Persada, Jakarta, 2002.

Hasby Ash-Shiddieqy, Peradilan dan Hukum Acara Islam, PT. Pustaka Rizki Putra, Semarang, 1977.

Jalaludin Al-Muhili dan Jalaludin Al-Suyuti, Tafsir Al-Jalalain, Ihya Al-Kutub Al-Arabiyah, Indonesia.

Juhaya S. Praja, Pengantar Hukum Islam Indonesia, PT. Rosdakarya, Bandung, 1981.

K. Wantjik Saleh, Hukum Acara Perdata RBG/HIR, Ghalia Indonesia, Jakarta, 1983.

M. Amin Aziz, Mengembangkan Bank Islam di Indonesia, Bangkit, Jakarta, 1990.

Mochtar Kusumaatmadja, Pengantar IImu Hukum, PT Alumni, Bandung, 2000.

----, Konsep-konsep Hukum dalam Pembangunan, PT. Alumni, Bandung, 2006.

Munir Fuady, Arbitrase Nasional: Alternatif Penyelesaian, Sengketa Bisnis, PT Citra Aditya Bakti, Bandung, 2003.

M. Husyein Umar dan A. Supriyani Kardono, Hukum dan Lembaga.Arbitrase di Indonesia, Elips, Jakarta, 1995.

M. Yahya Harahap, Ruang Lingkup Permasalahan Eksekusi Bidang Perdata, PT. Gramedia, Jakarta, 1989.

-----, Arbitrase, Pustaka.Kartini, Jakarta, 1991.

-----, Beberapa Tinjauan Mengenai Sistem Peradilan dan Penyelesaian Sengketa, PT. Citra Aditya Bakti, Bandung, 1997. 
Muhammad Ali Ash-Shobuni, Shofwatu Al-Tafasiir, Dar Al-Kutub Al-Islamiyyah, 1999.

Muhammad Syafi'i Antonio, Bank Syariah dari Teori ke Praktik, Gema Insani, Jakarta, 2001.

N,J. Coulson, A History Of Islamic Law, Edinburg University Press, London, 1964.

Otje Salman, Ikhtisar Filsafat Hukum, cet pertama, Armico, Bandung, 1987.

----, Ikhtisar Filsafat Hukum, cet ketiga, Armico, Bandung, 1992.

Quraish Shihab, Tafsir Al-Mishbah, Volume 2, PT. Lentera Hati, Jakarta, 2000.

----, Tafsir Al-Mishbah, Volume 13, PT. Lentera Hati, Jakarta, 2000.

Rachmat Syafe'i, Fiqih Muamalah, Pustaka Setia, Bandung, 2004.

Rachmadi Usman, Aspek-aspek Hukum Perbankan Islam, PT Citra Aditya Bakti, Bandung, 2002.

-----, Pilihan Penyelesaian Sengketa Di Luar Pengadilan, PT. Citra Aditya Bhakti, Bandung, 2003.

Sutan Remi Syahdeini, Perbankan Islam dan Kedudukannya dalam Tata Hukum Perbankan Indonesia, cet kesatu, PT Pustaka Utama Grafiti, Jakarta, 1999.

Sunaryati Hartono, Hukum Ekonomi Pembangunan Indonesia, cet kedua, Badan Pembinaan Hukum Nasional Dapartemen Kehakiman, Binacipta, Jakarta, 1988.

Suyud Margono, ADR \& Arbitrase: Proses Pelembagaan dan Aspek Hukum, Ghalia Indonesia, Bogor, 2004.

Subekti, Aneka Perjanjian, PT Citra Aditya Bakti, Bandung, 1995.

----, Arbitrase Perdagangan, Binacipta, Bandung, 1979.

Sudargo Gautama, Arbitrase Dagang Internasional, Alumni, Bandung, 1979.

Soerjono Soekanto, Pengantar Penelitian Hukum, Penerbit. UI-Press, Jakarta, 1986.

Salim, Pengantar Hukum Perdata Tertulis (BW), Sinar Grafika, Yogyakarta, 2002.

Suhrawardi K.Lubis, Hukum Ekonomi Islam, Sinar Grafika, Jakarta, 2000.

Sayyid Sabiq, Fiqh Sunnah, Juz I, Dar al-Fikr, Beirut, 1997.

----, Fiqih Sunah, Juz II, Dar al-Fikri, Beirut, 1983.

----, Fiqih Sunnah, Jilid III, PT. Al-Ma'arif, Bandung, 1988.

----, Fiqih Sunnah, Jilid 13, PT. Al-Ma'arif, Bandung, 1997.

Warkum Sumitro, Asas-asas Perbankan Islam dan Lembaga-lembaga Terkait (Bamui dan Takaful) Di Indonesia, PT RajaGrafindo Persada, Jakarta, 1997.

Wirdyaningsih, (et.all)., Bank dan Asuransi Islam di Indonesia, PT. Kencana Prenada MediaFH UI, Jakarta, 2006.

Yudha Bhakti Ardhiwisastra, Penafsiran dan Konstruksi Hukum, PT Alumni, Bandung, 2000.

\section{B. Legislation}

Redaksi Sinar Grafika, UUD 1945 Hasil Amandeman dan Proses Amandemen UUD 1945 secara lengkap (pertama 1999-keempat 2002), Sinar Grafika, Jakarta, 2002.

Kitab Undang-undang Hukum Perdata (BW).

Undang-undang Nomor 14 Tahun 1970 Tentang Ketentuan-ketentuan Pokok Kekuasaan Kehakiman.

Undang-undang Nomor 1 Tahun 1974 Tentang Perkawinan.

Undang-undang Nomor 7 Tahun 1989 Tentang Peradilan Agama.

Undang-undang Nomor 7 Tahun 1992 Tentang Perbankan.

Undang-undang Nomor 10 Tahun 1998 Tentang Perubahan Atas Undang- undang Nomor 7 Tahun 1992 Tentang Perbankan. 
Undang-undang Nomor 30 Tahun 1999 Tentang Arbitrase dan Alternatif Penyelesaian Sengketa.

Undang-undang Nomor 35 Tahun 1999 Tentang Perubahan Atas Undang- undang Nomor

14 Tahun 1970 Tentang Ketentuan-ketentuan Pokok Kekuasaan Kehakiman.

Undang-undang Nomor 4 Tahun 2004 Tentang Kekuasaan Kehakiman.

Undang-undang Nomor 25 Tahun 2004 Tentang Sistem Perencanaan Pembangunan Nasional (SPPN).

Undang-undang Nomor 3 Tahun 2006 Tentang Perubahan Atas Undang- undang Nomor 7 Tahun 1989 Tentang Peradilan Agama.

Peraturan Pemerintah Nomor 9 Tahun 1975 Tentang Pelaksanaan Undang- undang Nomor 1 Tahun1974 Tentang Perkawinan.

Peraturan Presiden Nomor 7 Tahun 2005 Tentang Rencana Pembangunan Nasional Jangka Menengah (RPJMN) Tahun 2004-2009.

Instruksi Presiden Nomor 1Tahun1991 Tentang Kompilasi Hukum Islam.

Kepmenag Nomor 154 Tahun 1991 Tentang. Pelaksanaan Instruksi Presiden Nomor I Tahun 1991 Tentang Kompilasi Hukum Islam.

\section{Chapter in Books}

Abdul Rahman Saleh, Badan Arbitrase Muamalah Indonesia-Arbitrase Islam Di Indonesia, BAMUI-BMI, Jakarta, 1994.

Ahmad Dimyati, Sejarah Lahirnya BAMUI-Arbitrase Islam Di Indonesia, BAMUI-BMI, Jakarta, 1994.

Fathurahman Djamil, Arbitrase dalam Perspektif Sejarah Islam-Arbitrase Islam Di Indonesia, BAMUI-BMI, Jakarta, 1994.

H.S. Prodjokusumo, Badan Arbitrase Muamalah Indonesia-Arbitrase Islam Di Indonesia, BAMUI-BMI, Jakarta, 1994.

Komar Kantaatmadja, Beberapa Masalah dalam Penerapan ADR di Indonesia, PT. Citra Aditya Bhakti, Bandung, 2001.

Muhammad Syafi'i Antonio, Perkembangan Lembaga Keuangan Islam- Arbitrase Islam Di Indonesia, BAMUI-BMI, Jakarta, 1994.

Mariam Darus Badrulzaman, Peranan BAMUI dalam Pembangunan Hukum NasionalArbitrase Islam Di Indonesia, BAMUI-BMI, Jakarta, 1994.

M. Yahya Harahap, Tempat Arbitrase Islam dalam Hukum Nasional-Arbitrase Islam Di Indonesia, BAMUI-BMI, Jakarta, 1994.

Satria Effendi M Zein, Arbitrase dalam Syariat Islam-Arbitrase Islam Di Indonesia, BAMUIBMI, Jakarta, 1994.

\section{E. Journal}

M. Yahya Harahap, "Beberapa Catatan Yang Perlu Mendapat Perhatian Atas UU No. 30 Tahun 1999 Tentang Arbitrase dan Alternatif Penyelesaian Sengketa", Jurnal Hukum Bisnis, Yayasan Pengembangan Hukum Bisnis, Jakarta, Volume 21 OktoberNovember 2002.

Munir Fuady, "Penyelesaian Sengketa Bisnis Melalui Arbitrase", Jurnal Hukum Bisnis, Yayasan Pengembangan Hukum Bisnis, Jakarta, Volume 210ktober-November 2002.

\section{F. Internet}


Hukumonline, "Penyelesaian Sengketa Bank Syariah Masih Diperdebatkan", www.hukumonline.com., 21September2006, pukul $13.50 \mathrm{Wib}$.

Yudo Paripurno, "National Sharia Arbitration Board Lebih Banyak Menangani Sengketa Perbankan", http://www.hukumonline.co.id., 03 Oktober 2006, pukul 11.00 Wib.

G. Etc

1. Paper

Anwar Nasution, (et.al), Laporan Konfrensi Tentang Krisis Ekonomi Di Indonesia, Kerjasama antara Australia National University dan Fakultas Ekonomi Universitas Indonesia, Jakarta, 1998, hlm.1.

2. Magazine

Ahmad Heidar, "Arti dan Mekanisme Musyawarah", Majalah Padjadjaran, P.T. Alumni, Bandung, 1992.

3. Newspaper

Agustianto, "Akar Krisis Ekonomi Dunia (Perspektif Syariah)", PT. Pelita Indonesia Baru, Jakarta Selatan, Kamis, 19 Juli 2007.

Ahmad Dimyati, "Dicari,Ulama Muamalat", dalam harian PELITA, Jakarta, senin 4 Januari 1993.

4. Dictionary

Tim Pena Prima, Kamus Besar Bahasa Indonesia, PT. Gita Media Press, Jakarta.

Mahmud Yunus, Kamus Arab-Indonesia, PT. Hidakarya Agung, Jakarta. 